\title{
Identification and Localization of a Novel Nucleolar Protein of High Molecular Weight by a Monoclonal Antibody
}

\author{
MARION S. SCHMIDT-ZACHMANN, BARBARA HÜGLE, \\ ULRICH SCHEER and WERNER W. FRANKE \\ Division of Membrane Biology and Biochemistry, Institute of Cell and Tumor Biology, \\ German Cancer Research Center, D-6900 Heidelberg, Germany
}

\begin{abstract}
A monoclonal murine antibody (No-114) is described which reacts specifically with a polypeptide of molecular weight $\left(M_{r}\right) 180000$ present in low-speed nuclear pellets from oocytes and somatic cells of Xenopus laevis and $X$. borealis and in isolated amplified nucleoli. Two-dimensional gel electrophoresis has revealed the acidic nature of this polypeptide (isoelectric at $\mathrm{pH}$ of ca 4.2 in the presence of $9.5 \mathrm{M}$ urea). A relatively large proportion of the protein is extracted at elevated ionic strength( i.e., at $0.4-0.5 \mathrm{M}$ alkali salt) in a form sedimenting at approx. $7-8 \mathrm{~S}$, compatible with a monomeric state. It is also extracted by digestion with RNase but not with DNase. In immunofluorescence microscopy, antibody No-114 stains intensely nucleoli of oocytes and all somatic cells examined, including the residual nucleolar structure of Xenopus erythrocytes which are transcriptionally inactive. During mitosis the antigen does not remain associated with the nucleolar organizer regions (NOR) of chromosomes but is released and dispersed over the cytoplasm until telophase when it re-associates with the reforming interphase nucleoli. At higher resolution the immunofluorescent region is often resolved into a number of distinct subnucleolar components of varied size and shape. Immunoelectron microscopy using colloidal gold-coupled secondary antibodies reveals that the $M_{r} 180000$ protein is confined to the dense fibrillar component of the nucleolus. This conclusion is also supported by its localization in the fibrillar part of segregated nucleoli of cells treated with actinomycin D. We conclude that nucleoli contain a prominent protein of $M_{r} 180000$ which contributes to the general structure of the dense fibrillar component of the interphase nucleolus, independent of its specific transcriptional activity.
\end{abstract}

In the past two decades considerable progress has been made in understanding the basic functional organization of the nucleolus. Combined morphological, biochemical, and autoradiographic data have established that the nucleolus is the site of the genes which code for pre-rRNAs, transcription of these genes, assembly of the pre-rRNA molecules with specific proteins into ribonucleoprotein complexes, and maturation of the preribosomal particles both at the RNA and protein level (for reviews see [1-3]). Based primarily on electron microscopic autoradiography of cells labeled with radioactive uridine, morphologically distinct components of nucleoli can be correlated with certain steps of the pathway of ribosome biogenesis [4-9]. Although nucleoli can display different shapes and arrangements of their component substructures, depending on the specific cell type and metabolic condition of the cell, there is general agreement that primary transcripts containing pre-rRNA are located in the dense fibrillar part of the 


\section{Schmidt-Zachmann et al.}

nucleolus, whereas the granular component contains preribosomal particles in advanced stages of maturation. An important step in defining the complex architecture of the nucleolus has been made possible with the availability of antibodies to RNA polymerase I, the enzyme responsible for the transcription of the rRNA genes [10]. Electron microscopic immunocytochemistry shows that transcriptionally active rRNA genes are located in the 'fibrillar centres' (FC) of nucleoli which appear to represent the interphase structure of the chromosomal 'nucleolus organizer' region (NOR) [11].

Several observations indicate that nucleoli cannot be considered as simple agglomerates of nucleolar chromatin, RNA polymerase I complexes, and transcription products but that other components are involved which contribute to their complex organization. For example, a system of proteinaceous karyoskeletal filaments, insoluble in low and high salt buffers, has been localized in the nucleolar cortex and is characterized as a major polypeptide of $M_{r} 145000$ [12-14]. In addition, coiled fibrillar bodies termed 'medusoid fibril bodies' which also seem to contain this protein have been shown to be located in the nucleolar periphery and elsewhere in the nucleoplasm [14, 15]. It is noteworthy that the formation of a nucleolus-like structure is not necessarily a consequence of the transcription of nucleolar genes. For example, in the anucleolate mutant embryo of Xenopus laevis, prominent 'pseudonucleoli' composed of compact fibrillar material appear in the absence of rRNA genes and their transcriptional products [16].

Aside from these structural elements, relatively few nucleolar proteins have been biochemically characterized and localized; most examples of these apparently represent ribonucleoproteins associated with transcriptional activity of the nucleolus [17-20]. In the present report we describe and characterize a novel nucleolus-specific protein which is not bound to preribosomal particles. This protein is a major constituent of the fibrillar component not only in transcriptionally active nucleoli but also in the transcriptionally inactive residual nucleolar structures of nucleated erythrocytes of Xenopus laevis.

\section{MATERIALS AND METHODS}

\section{Biological Materials}

Clawed toads of the species Xenopus laevis were purchased from the South African Snake Farm (Fish Hoek, Cape Province, South Africa). Toads of the species Xenopus borealis were a gift from Dr M Fischberg (University of Geneva). Newts, Triturus cristatus carnifex, and salamanders, Pleurodeles waltii, were reared in our laboratory. Frogs (Rana temporaria), chicken and rats (SpragueDawley), were obtained from animal farms.

Cultured cells from a human tumor (HeLa) and from kidney epithelia of rat kangaroo (PtK2) and Xenopus laevis (XLKE, kidney epithelial cells; line A6, American Type Culture Collection) were grown as described [21].

\section{Monoclonal Antibodies}

Nuclei of Xenopus laevis oocytes were isolated essentially according to the method of Scalenghe et al. [22] with some modifications [23]. Nuclear homogenates were centrifuged for $10 \mathrm{~min}$ at $3500 \mathrm{~g}$ at 
$4^{\circ} \mathrm{C}$. The resulting pellet, including nucleoli, nuclear membranes, and chromosomes was designated 'low-speed pellet' (LSP) and used for immunization. For the first immunization, LSP obtained after centrifugation of $3 \mathrm{ml}$ nuclear homogenate, collected from $3000-5000$ nuclei, was emulsified in complete Freund's adjuvant and injected subcutaneously into a female BALB/c mouse (ZentralVersuchstieranstalt, Hannover), followed by a second injection of the same amount of antigen in incomplete Freund's adjuvant 35 days after the initial immunization. For the booster injection at day 56 , the LSP of another $3 \mathrm{ml}$ nuclear homogenate was suspended in sterile PBS, sonicated and injected intraperitoneally. Three days after the booster injection, the spleen cells were fused with myeloma cell line Ag 8.653 at a ratio of 10:1 essentially as described by Köhler \& Milstein [24]. Hybridoma culture supernatants were tested for antibody production by immunofluorescence microscopy, using frozen sections of Xenopus laevis liver and ovaries. Positive cultures were subcloned twice by limited dilution.

For production of ascites fluid containing the specific monoclonal antibody, BALB/c mice were injected intraperitoneally with $0.5 \mathrm{ml}$ Pristane (2,6,10,14-tetramethylpentadecane; Sigma, München). One week later, $1 \times 10^{6}$ hybridoma cells were injected intraperitoneally. After 8-14 days, ascites fluid was removed under sterile conditions. Tumour cells were spun down, and the supernatant was used for antibody purification.

Immunoglobulin subclasses were determined by double immunodiffusion as described by Ouchterlony [25], using double-concentrated cell culture supernatants and subclass-specific antibodies to mouse Ig (from Miles-Yeda, Rehovot, Israel) diluted 1:4 in PBS.

For purification of antibodies, ascites fluid was diluted to a protein concentration of $1-2 \mathrm{mg} / \mathrm{ml}$ and applied to an Affigel-Blue column (Bio-Rad, München). Mouse immunoglobulins were eluted from the column by $150 \mathrm{mM} \mathrm{NaCl}, 20 \mathrm{mM}$ Tris- $\mathrm{HCl}(\mathrm{pH} 8)$ and concentrated by vacuum dialysis against PBS to a protein concentration of $1 \mathrm{mg} / \mathrm{ml}$. Purified immunoglobulins were stored in aliquots at $-20^{\circ} \mathrm{C}$.

\section{Immunofluorescence Microscopy}

Small pieces of tissue (ovary, liver, testis, heart) from Xenopus laevis and other species (Xenopus borealis, Rana temporaria, Pleurodeles waltlii, Triturus cristatus, rat, and chicken) were quickfrozen as described [26]. Cryostat sections of $5 \mu \mathrm{m}$ thickness were air-dried. Blood smears were prepared from Xenopus laevis and also air-dried.

Cultured cells of Xenopus laevis and other species (HeLa, PtK2) were grown on coverslips. In some experiments, actinomycin D (Serva, Heidelberg) was added to the culture medium to a final concentration of $5 \mu \mathrm{g} / \mathrm{ml}$. Cells were exposed to the drug for $4 \mathrm{~h}$. Cells and cryostat sections were processed for immunofluorescence microscopy as described [27].

After $15 \mathrm{~min}$ of incubation with antibody (hybridoma cell culture supernatant or Ig from ascites fluid) the specimens were washed three times in PBS and then incubated for 15 min with rhodaminelabelled goat anti-mouse Ig (Miles-Yeda) diluted 1:20 in PBS. Photographs were taken with a Zeiss Photomicroscope III (Zeiss, Oberkochen) equipped with epifluorescence optics (40X and $63 \times$ oil immersion objectives). For general control experiments, cell culture supernatants of non-producing hybridoma cell lines were used. For specific controls, a monoclonal murine antibody to protein S1 of the small ribosomal subunit (antibody RS1-105; to be described in detail elsewhere [57]), rabbit antibodies to RNA polymerase I $[10,11]$ and murine antibodies to the karyoskeletal $M_{r} 145000$ protein of the nucleolar periphery [13] were used in parallel.

\section{Electron Microscopy}

Blood of a decapitated Xenopus laevis was dropped directly into fixative (2.5\% glutaraldehyde containing $50 \mathrm{mM} \mathrm{KCl}$ and $2.5 \mathrm{~m} \mathrm{MgCl}_{2}$, buffered with $50 \mathrm{mM}$ sodium cacodylate to $\mathrm{pH} 7.2$ ) at room temperature. After $30 \mathrm{~min}$, the suspension was gently centrifuged, and the pellet was washed several times in cacodylate buffer, followed by postfixation in $2 \% \mathrm{OsO}_{4}$ at $4^{\circ} \mathrm{C}$ for $1 \mathrm{~h}$. After several washes in distilled water, the pellet was dehydrated in graded ethanol solutions and finally embedded in Epon 812. Ultrathin sections were stained according to standard procedures.

For electron microscopic immunolocalization, cryostat sections through Xenopus laevis liver were prepared as described above. After dehydration with acetone, the air-dried sections were incubated with the primary antibody $(50 \mu \mathrm{g} \mathrm{Ig} / \mathrm{ml}$ ) for $30 \mathrm{~min}$, washed in PBS and then incubated overnight with goat anti-mouse immunoglobulin coupled to $5 \mathrm{~nm}$ colloidal gold (Janssen Life Sciences, Beerse, 


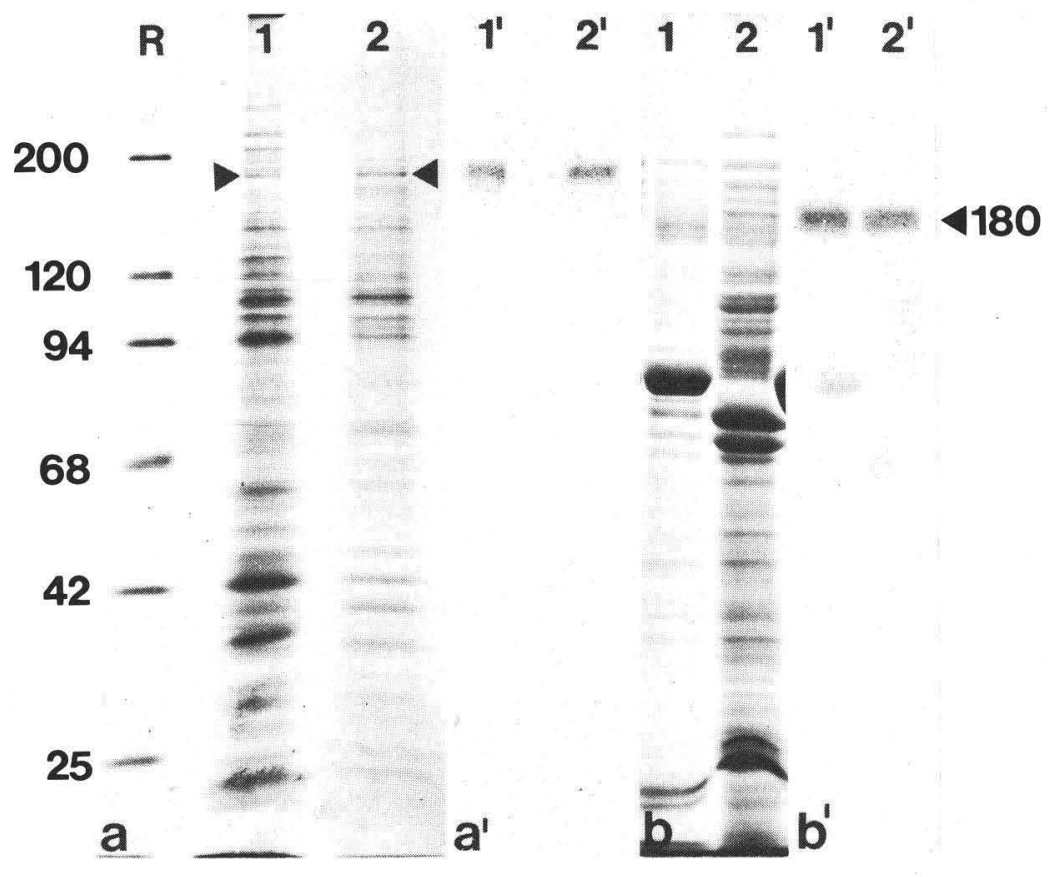

Fig. I. Identification of the polypeptide reacting with monoclonal antibody No-114 in different nuclear fractions from Xenopus laevis oocytes by SDS-PAGE and immunoblotting. (a) Coomassie blue staining of proteins 1, extracted from low-speed pellet (LSP) with PBS containing $0.3 \mathrm{M} \mathrm{KCl}$ and 2 , of isolated purified nucleoli after separation on $10 \%$ acrylamide gels. Reference proteins $R$; (molecular weights are indicated in $10^{3}$ units) are from top to bottom: myosin heavy chain $\left(M_{r}\right.$ $200000), \beta$-galactosidase $\left(M_{r}\right.$ 120000), phosphorylase a $\left(M_{r} 94000\right)$, bovine serum albumin $\left(M_{r}\right.$ $68000)$, actin $\left(M_{r} 42000\right)$ and chymotrypsinogen $\left(M_{r} 25000\right)$. $\left(a^{\prime}\right)$ Autoradiograph corresponding to the gel shown in $(a)$ obtained after immunoblotting and incubation with cell culture supernatant from hybridoma clone No-114. Antibody No-114 reacts selectively with a polypeptide of $M_{r} 180000$ present in $1^{\prime}$, LSP fraction, as well as in $2^{\prime}$, purified nucleoli, which is indicated in $(a)$ by arrowheads. (b) Coomassie Blue staining of LSP proteins solubilized after digestion with $I$, pancreatic RNase alone; 2 , by subsequent extraction of the residual pellet with PBS containing $0.3 \mathrm{M} \mathrm{KCl}$, separated by SDS-PAGE (7.5\%). $\left(b^{\prime}\right)$ Corresponding autoradiograph after immunoblotting with No-114 antibody, showing the presence of the antigenic polypeptide (arrowhead in right margin) in the 1', RNaseextract; and 2', in the supernatant after extraction of the RNase-treated pellet at elevated salt concentration.

Belgium) diluted 1:2 in PBS. After several washes in PBS, specimens were fixed and processed for electron microscopy as described [11]. Micrographs were taken with a Zeiss EM-10 electron microscope.

\section{Fractionation Experiments}

For detection of the antigenic polypeptide(s), supernatant fractions of the LSP obtained after various extraction procedures and centrifugation at $3500 \mathrm{~g}$ were used. LSPs were treated with $(i) 0.3$ $\mathrm{M} \mathrm{KCl}$ in PBS for $20 \mathrm{~min}$ at $4^{\circ} \mathrm{C}$; (ii) pancreatic RNase (Boehringer, Mannheim) at a concentration of $10 \mu \mathrm{g} / \mathrm{ml}$ in $50 \mathrm{mM} \mathrm{NaCl}, 10 \mathrm{mM}$ Tris $-\mathrm{HCl}$ ( $\mathrm{pH}$ 7.2) for $30 \mathrm{~min}$ at room temperature; (iii) DNase I (Worthington, Freehold, N.J.) at a concentration of $10 \mu \mathrm{g} / \mathrm{ml}$ in $2 \mathrm{mM} \mathrm{MgCl}, 10 \mathrm{mM}$ Tris-HCl, $1 \mathrm{mM}$ $\mathrm{CaCl}_{2}(\mathrm{pH}$ 7.3) for $30 \mathrm{~min}$ at room temperature; (iv) RNase or DNase as described under (ii) or (iii), followed by extraction with $0.3 \mathrm{M} \mathrm{KCl}$ in PBS. 


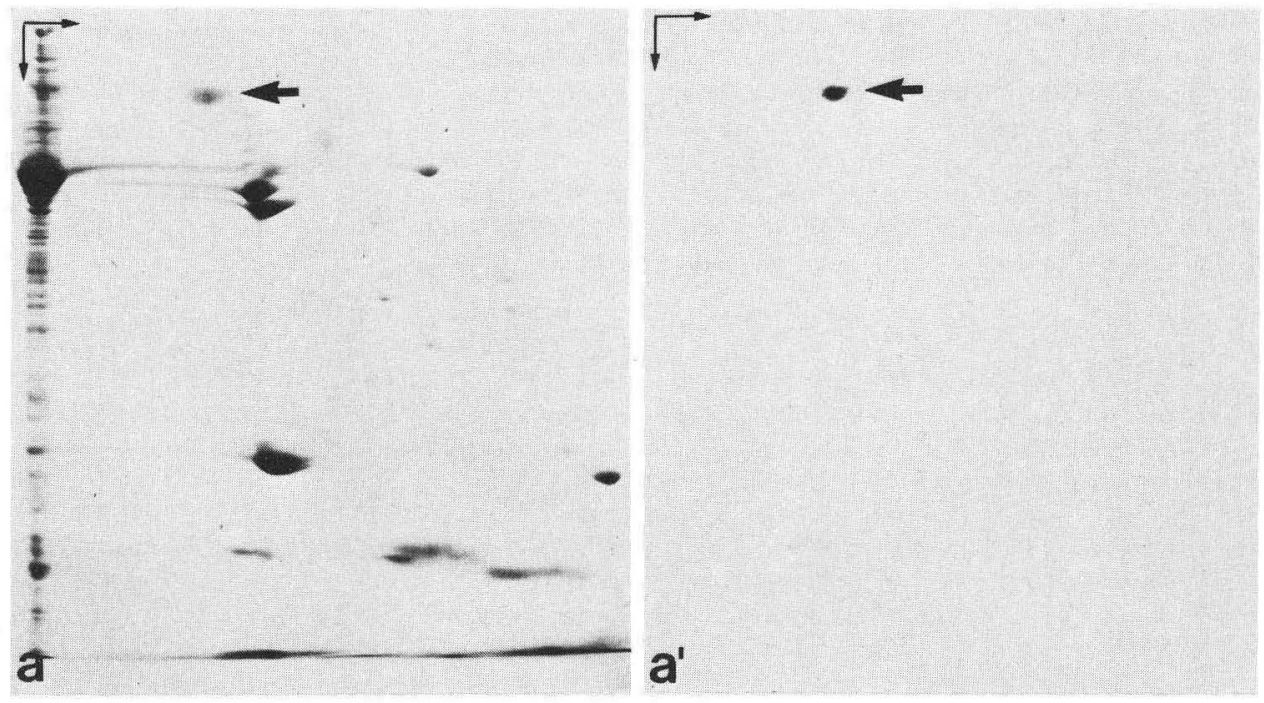

Fig. 2. Identification of the antigen recognized by No-114 antibody by two-dimensional gel electrophoresis and immunoblotting. (a) Coomassie Blue staining of LSP polypeptides from oocyte nuclei of Xenopus laevis separated by two-dimensional gel electrophoresis (first dimension, indicated by horizontal arrow: non-equilibrium $\mathrm{pH}$-gradient (NEPHG); second dimension, indicated by vertical arrow: SDS-PAGE in $10 \%$ acrylamide gel) of LSP proteins solubilized with PBS containing $0.3 \mathrm{M}$ $\mathrm{KCl}$. $\left(a^{\prime}\right)$ Corresponding autoradiograph after immunoblotting with No-114 antibody. The position of the antigenic polypeptide of $M_{r} 180000$ with an apparent pI of 4.2 is indicated by arrows in $(a)$ and $\left(a^{\prime}\right)$.

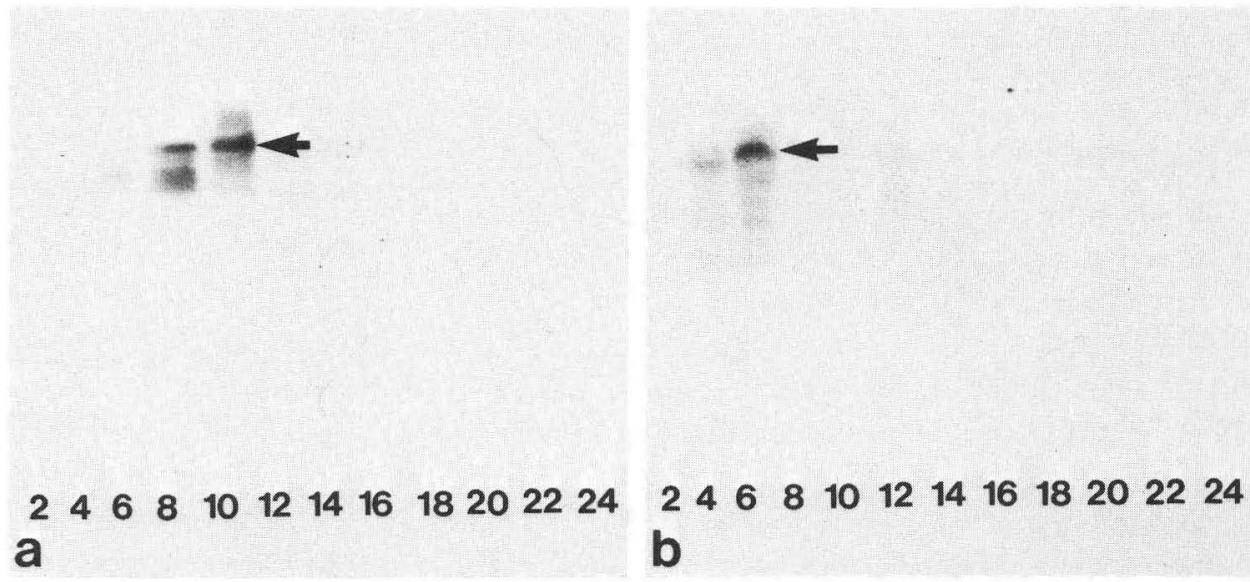

Fig. 3. Separation of LSP proteins from Xenopus oocyte nuclei obtained by extraction with PBS containing (a) $0.3 \mathrm{M} \mathrm{KCl}$; or $(b)$ treatment with pancreatic RNase by sucrose gradient centrifugation and subsequent gel electrophoresis of the gradient fractions (SDS-18\% polyacrylamide gel). The major polypeptide band reacting with No-114 antibody is identified by immunoblotting (indicated by arrows; Coomassie Blue staining of the gels is not shown here). Reference proteins, separated in a parallel gradient, have been recovered in the following fractions: 6 ; bovine serum albumin, $4.3 \mathrm{~S} ; 8$, bovine $\mathrm{IgG}, 6.5 \mathrm{~S} ; 13$, catalase, $11.3 \mathrm{~S}$. Sedimentation is from left to right (fraction numbers $1-24$, indicated on bottom line). 
In some experiments, extracted proteins were fractionated in 5-30\% sucrose gradients made up in $83 \mathrm{mM} \mathrm{KCl}, 17 \mathrm{mM} \mathrm{NaCl}, 2 \mathrm{mM} \mathrm{MgCl} 2,0.5 \mathrm{mM}$ phenylmethyl sulfonylfluoride, $2.5 \mathrm{mM}$ dithiothreitol, $10 \mathrm{mM}$ Tris- $\mathrm{HCl}(\mathrm{pH} 7.2)$. Gradient centrifugations were at $36000 \mathrm{rpm}$ for $16 \mathrm{~h}$ in a Beckman L5-50 ultracentrifuge, using a SW40 rotor, at $4^{\circ} \mathrm{C}$. Fractions of $0.4 \mathrm{ml}$ were collected and proteins were precipitated by $15 \%$ TCA. Reference proteins were examined in parallel gradients.

Purified nucleoli of germinal vesicles were prepared by fluorescence-activated sorting of fluorochrome-stained nucleoli as described previously [12]. Isolated nucleoli were pelleted at $3500 \mathrm{~g}$ for 10 $\min$ at $4^{\circ} \mathrm{C}$ and processed directly for gel electrophoresis.

\section{Gel Electrophoresis and Immunoblotting Experiments}

Slab gel electrophoresis in the presence of sodium dodecylsulfate (SDS) was performed at different acrylamide concentrations, using either the conditions of Laemmli [28] or those described by Thomas \& Kornberg [29]. For two-dimensional gel electrophoresis, isoelectric focusing (IEF) or non-equilibrium pH-gradient electrophoresis (NEPHGE) was used in the first dimension ([30]; for modifications see [31]). Gels were stained with Coomassie Blue or with silver, using the procedure described [32].

For immunoblotting, polypeptides were renatured on the gel by incubation in $4 \mathrm{M}$ urea, $50 \mathrm{mM}$ $\mathrm{NaCl}, 20 \mathrm{mM}$ EDTA, $0.2 \mathrm{mM}$ dithiothreitol, $10 \mathrm{mM}$ Tris- $\mathrm{HCl}(\mathrm{pH} 7.5)$ for $1.5 \mathrm{~h}$ [33], and then electrophoretically transferred to nitrocellulose paper according to Towbin et al. [34]. After several washes and saturation with $1 \%$ bovine serum albumin (BSA) in $140 \mathrm{mM} \mathrm{NaCl}, 10 \mathrm{mM}$ Tris- $\mathrm{HCl}(\mathrm{pH}$ 7.4), nitrocellulose sheets were incubated with hybridoma cell culture supernatant for $2 \mathrm{~h}$ at room temperature or overnight at $4{ }^{\circ} \mathrm{C}$. Washed nitrocellulose sheets were incubated for $2 \mathrm{~h}$ with goat antimouse Ig (Conco Lab. Division, Wiesbaden, FRG) labelled with ${ }^{125} \mathrm{I}$ by the chloramine-T-procedure according to Hunter [35]. Nitrocellulose sheets were washed, dried and exposed to Kodak X-ray film for $1-10$ days at $-70^{\circ} \mathrm{C}$.

\section{RESULTS}

\section{Antibody}

Murine antibody No-114 is an IgG1 with a high affinity and high avidity in binding to a nucleolar protein. The hybridoma producing No-114 can be grown in culture and ascites form.

\section{Identification of Antigen}

When proteins of whole oocyte nuclei from Xenopus laevis or low-speed pellets obtained from nuclear homogenates were separated by SDS-PAGE and exposed to antibody No-114, a polypeptide band of approx. $M_{r} 180 \mathrm{kD}$ was found to bind the antibody specifically. When the material of low-speed pellets was extracted with buffers of increasing ionic strength, a relatively large proportion of the $M_{r} 180000$ protein was recovered in a form no longer pelletable by centrifugation at $3500 \mathrm{~g}$ for $10 \mathrm{~min}$ after incubation with buffers containing alkali salt concentrations of $0.4 \mathrm{M}$ and above (fig. $1 a, a^{\prime}$, lanes $1,1^{\prime}$ ). This polypeptide was found to be significantly enriched in isolated extrachromosomal oocyte nucleoli (fig. $1 a, a^{\prime}$, lanes $2,2^{\prime}$ ). In such nucleolar fractions the $M_{r} 180000$ polypeptide

Fig. 4. Immunofluorescence microscopy on frozen sections through previtellogenic oocytes of Xenopus laevis in (a) epifluorescence; $(b)$ phase contrast optics after incubation with No-114 antibody. Nucleoli of the germinal vesicles and of the surrounding epithelial $(E)$ cells are brightly fluorescing. In addition, some small granular fluorescent entities are recognized in the oocyte nuclei $(N)$. Bar, $20 \mu \mathrm{m}$.

Exp Cell Res 153 (1984) 


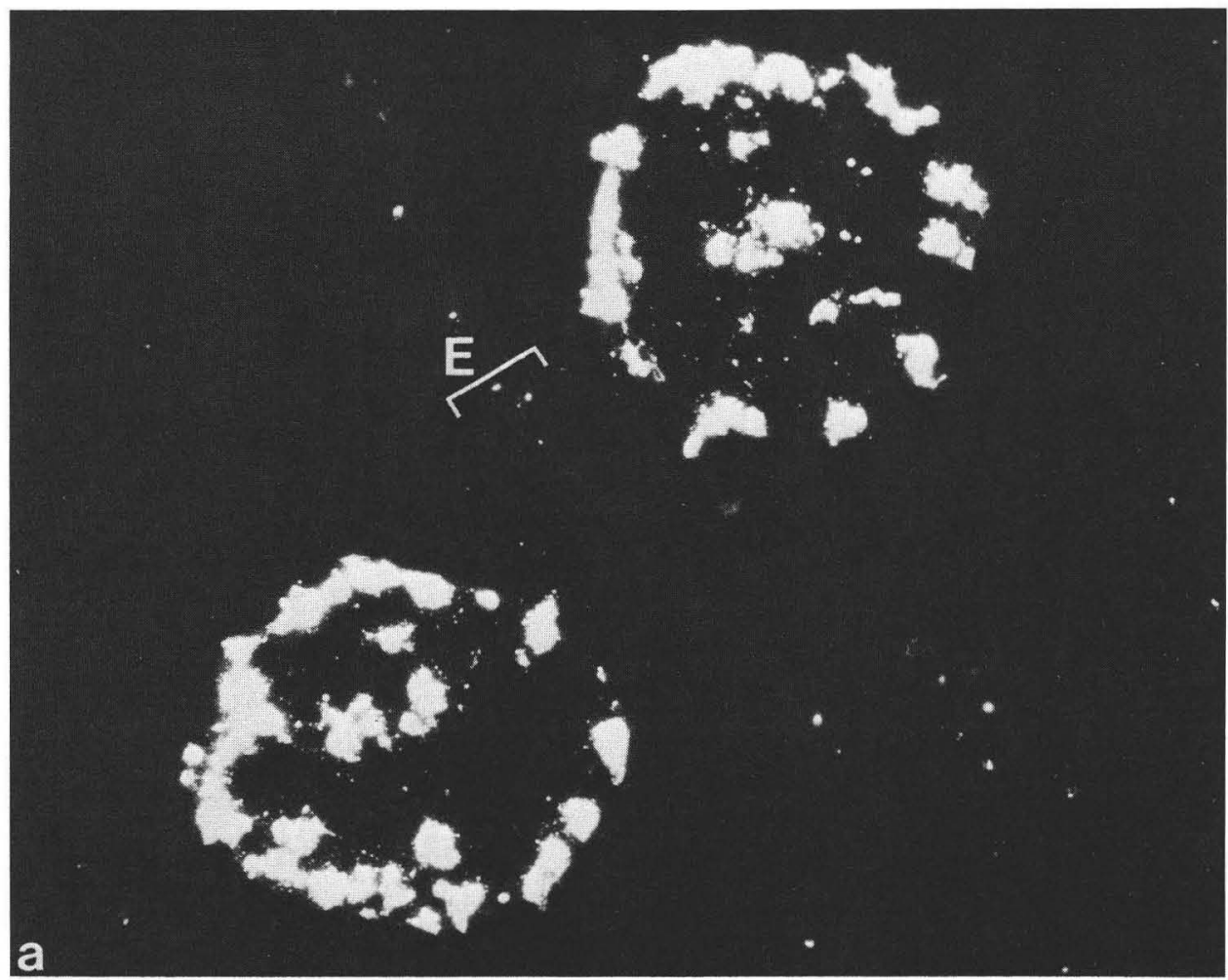

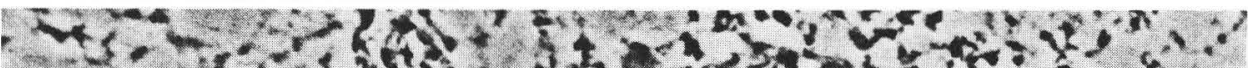

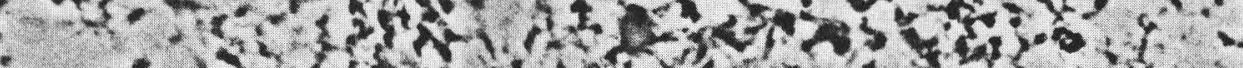

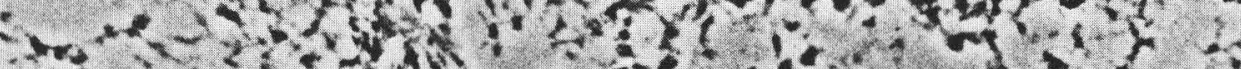

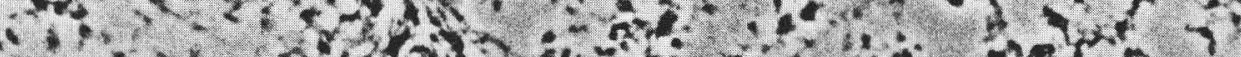

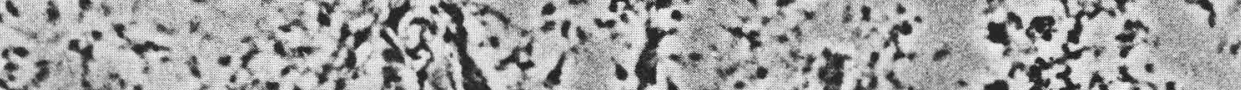

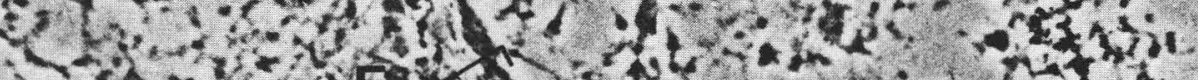

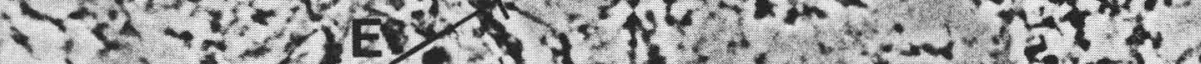

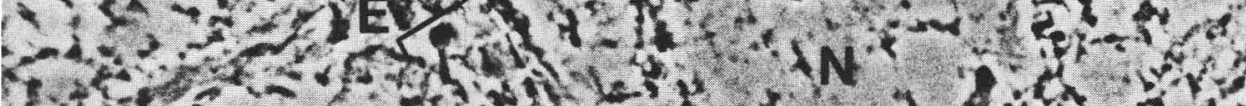

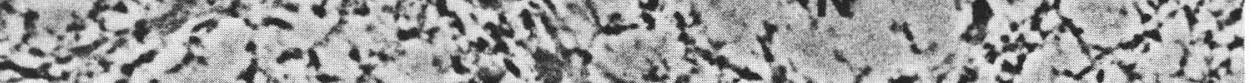

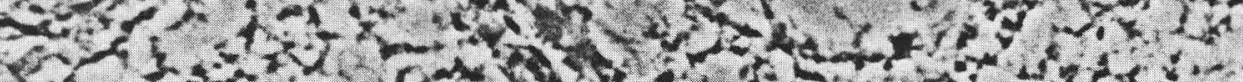

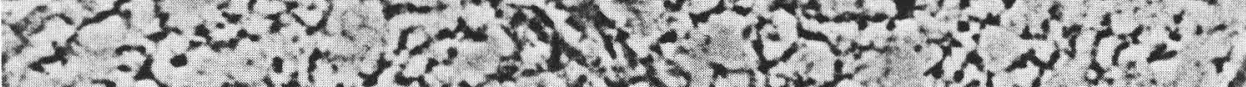

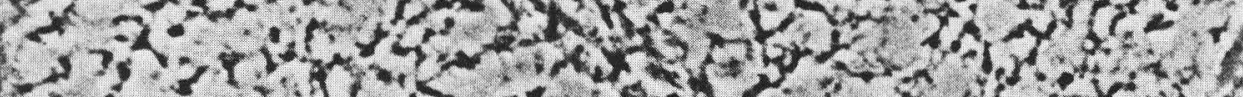

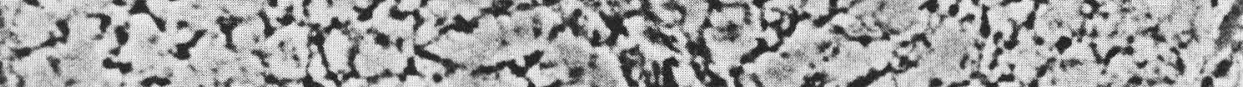

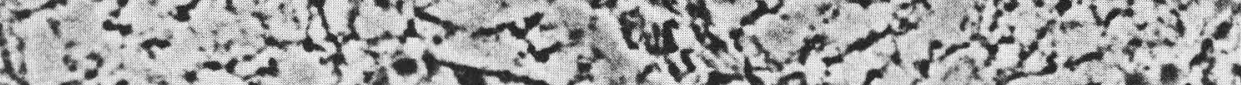

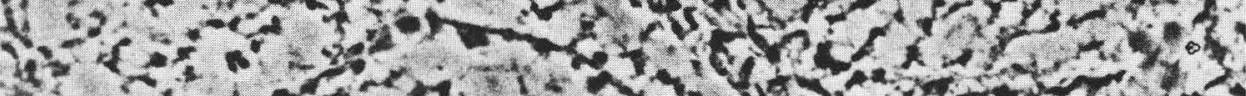

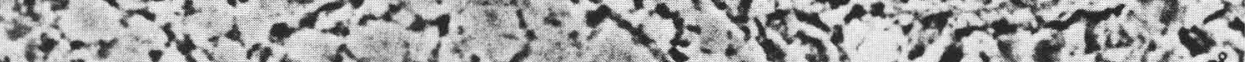

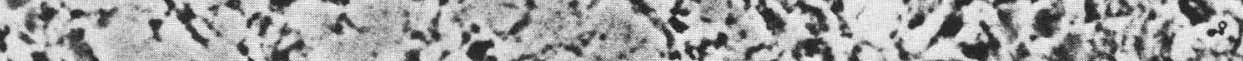

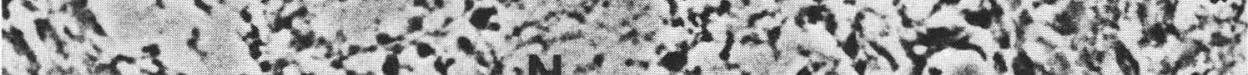
S.

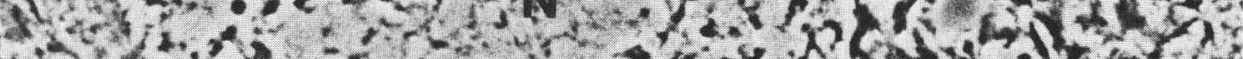

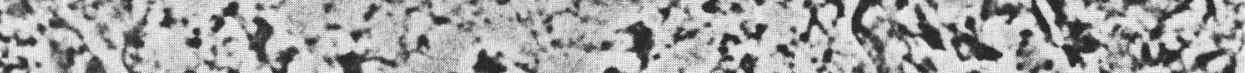

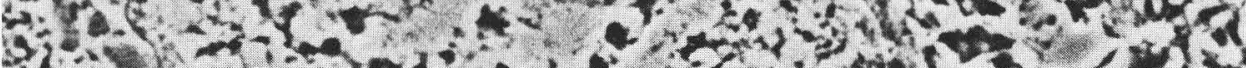

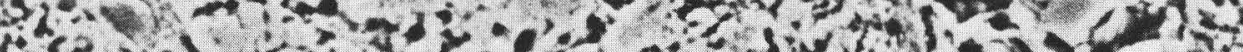

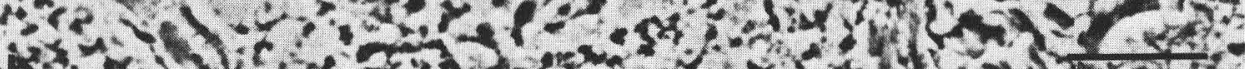

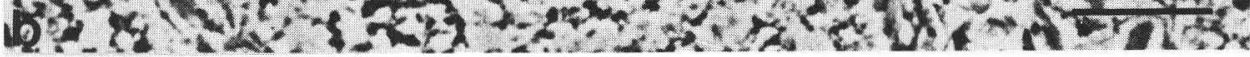




\section{Schmidt-Zachmann et al.}

was among the most abundant components and, together with a band of approx. $M_{r} 105000$ and the karyoskeletal protein of ca $M_{r} 145000$, represented the only conspicuous polypeptides larger than 100000. A considerable amount of this protein could be extracted by treatment with pancreatic ribonuclease (fig. $1 b, b^{\prime}$, lanes $1,1^{\prime}$ ), whereas treatment with DNase I did not result in a significant release of material containing this protein (data not shown). In order to release maximal amounts of this protein, combined sequential treatment with RNase and PBS containing $0.3 \mathrm{M} \mathrm{KCl}$ was used (fig. $1 b, b^{\prime}$, lanes $2,2^{\prime}$ ).

By using two-dimensional gel electrophoresis of LSP proteins for the immunoblotting test, we could identify a major polypeptide component of $M_{r} 180000$ which was very acidic (fig. 2). Using isoelectric focusing (data not shown) an isoelectric $\mathrm{pH}$ of approx. 4.2 was determined for the $9.5 \mathrm{M}$ urea-solubilized polypeptide.

In some immunoblotting experiments we noted some minor polypeptide components with $M_{r}$ values of about 100000 and below, at highly variable intensities (see also fig. $3 a$ ). We tentatively regard these minor components as artifacts arising from proteolytic breakdown.

By using sucrose gradient centrifugation, we could show that the $M_{r} 180000$ polypeptide released at elevated ionic strength (fig. $3 a$ ) or by RNase treatment (fig. $3 b$ ) sediments at 7-8S, indicating that it was not contained in large particles, but was most probably present as a monomeric polypeptide. In such experiments we sometimes noted a slight shift to a lower apparent S-value after digestion with RNase (fig. $3 b$ ). The significance of this observation is not clear. We did not find any indication of the presence of RNA in the peak fractions containing the $M_{r}$ 180000 protein, judging by the $A_{260}$ and $A_{280}$ ratios (data not shown).

In preliminary experiments, a polypeptide of similar size was identified as the No-114 antibody binding component in LSP fractions from some other Xenopus cells, notably cultured A6 (data not shown).

\section{Immunofluorescence Microscopy on Tissue Sections}

Immunofluorescence microscopy using antibody No-114 on cryostat sections of ovaries of Xenopus laevis and $X$. borealis showed strong staining of the large nucleoli which were located chiefly on the periphery of the oocyte nuclei and of the much smaller nucleoli of the follicle epithelial cells (fig. 4). In addition, some positively-stained small particles, not very frequent in most cells, were seen throughout the nucleoplasm of the oocytes (fig. $4 a$ ).

In other cell types, such as hepatocytes of Xenopus laevis liver, one relatively large and strongly-stained nucleolus was found per cell (fig. $6 a, b$ ) suggestive of fusion of nucleoli. By contrast, endothelial cells, fibroblasts and blood cells present in the same tissue showed much smaller nucleoli.

Nucleolar localization of the $M_{r} 180000$ protein-or a similarly sized protein immunologically related to it-was noted in cells of all other tissues examined. For example, in testicular tissue (fig. $5 a, b$ ) a strong reaction was noted in the 

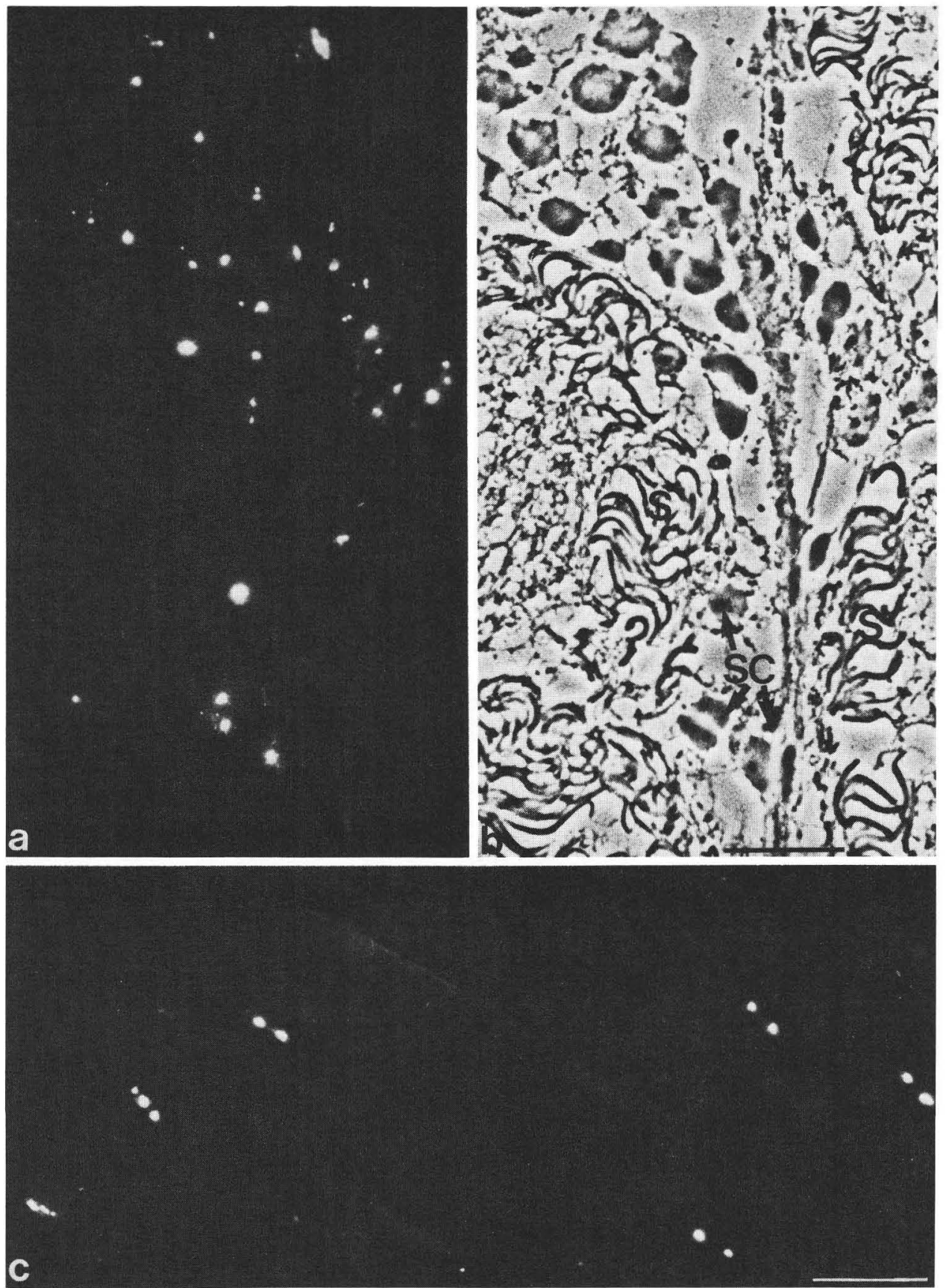

Fig. 5. Immunolocalization of No-114 antigen by immunofluorescence microscopy on frozen sections of (a) Xenopus laevis testis; the corresponding phase contrast image is shown in $(b)$ and heart muscle cells $(c)$. In testis, positively stained nucleoli are seen in Sertoli cells $(S C)$, spermatogonia and spermatocytes, whereas spermatids and spermatozoa $(S)$ are negative. In the more or less spindleshaped nuclei $(c)$ of heart muscle cells nucleoli show a bright fluorescence. Bar, $20 \mu \mathrm{m}$. 


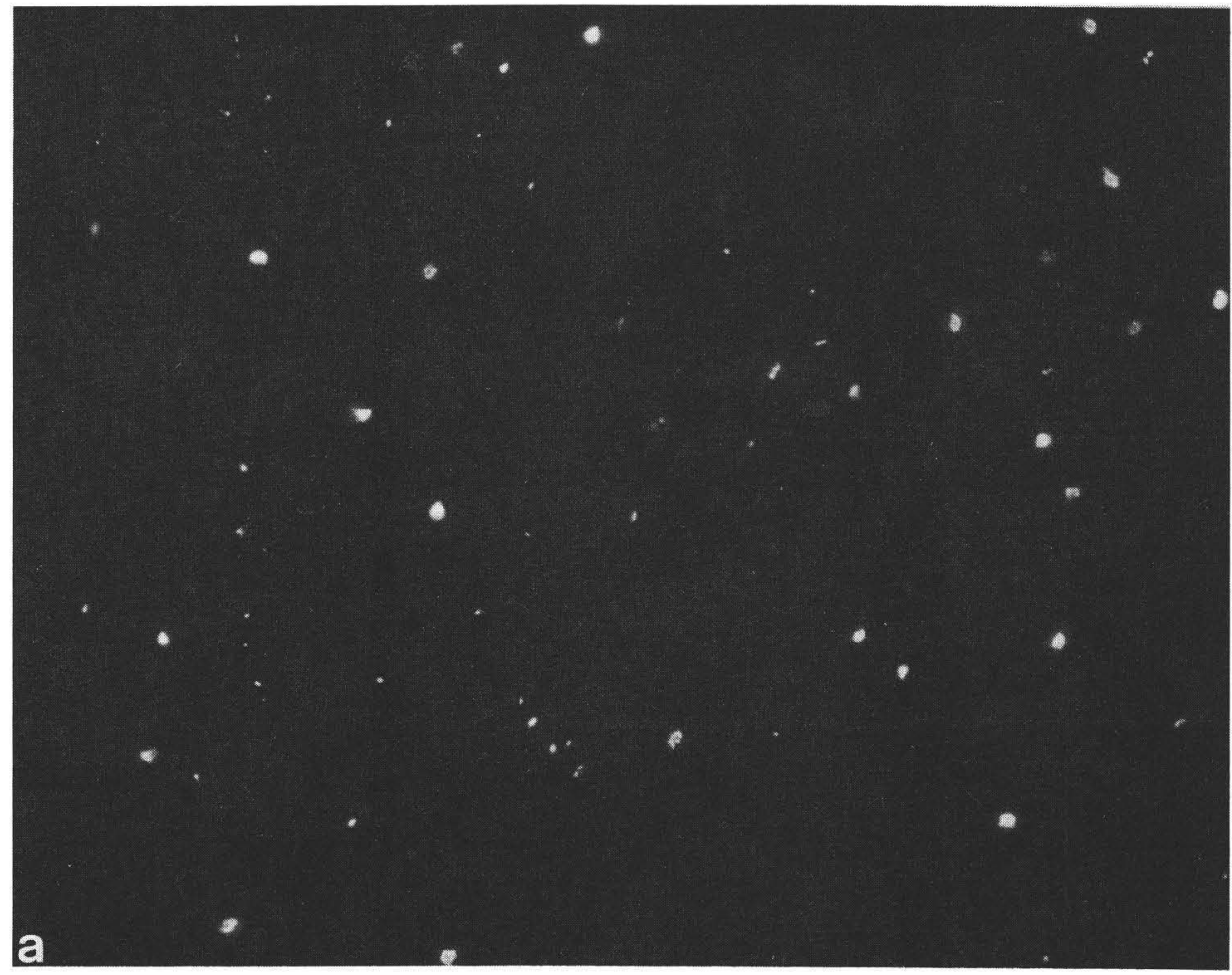

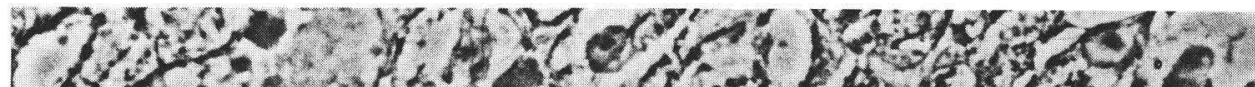

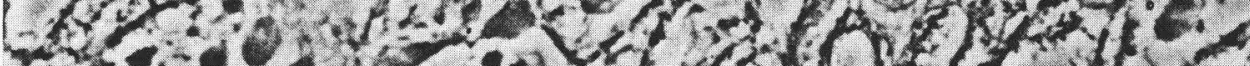
76 ; 3 a

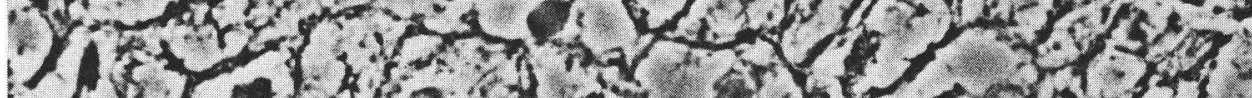

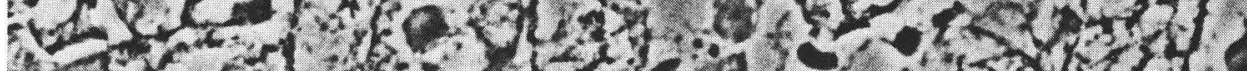

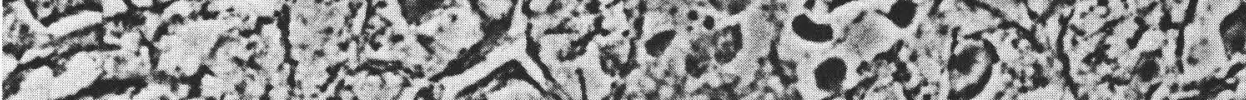

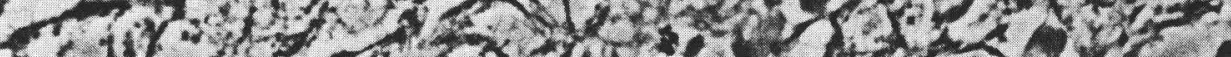

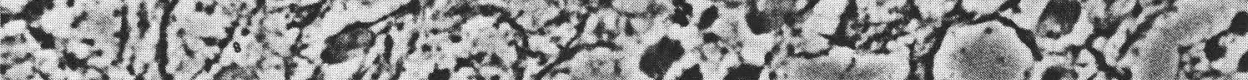

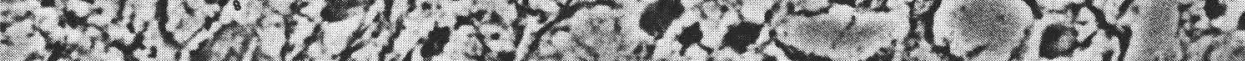
6.

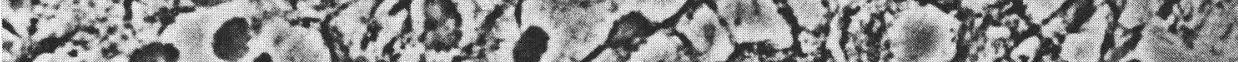

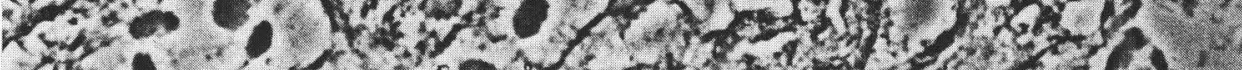

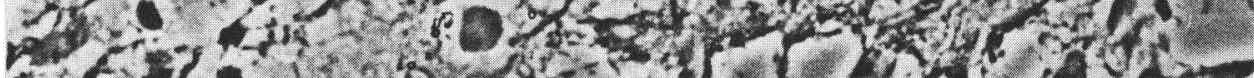

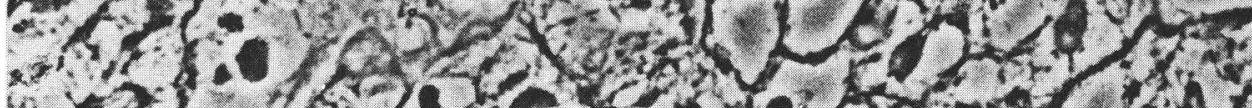

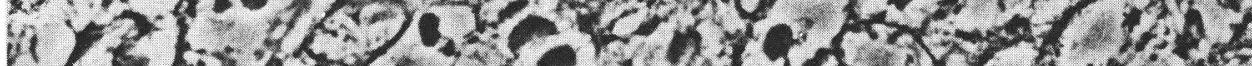

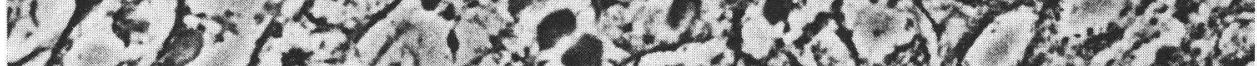

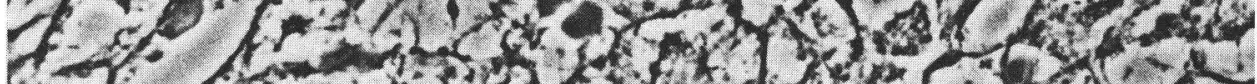

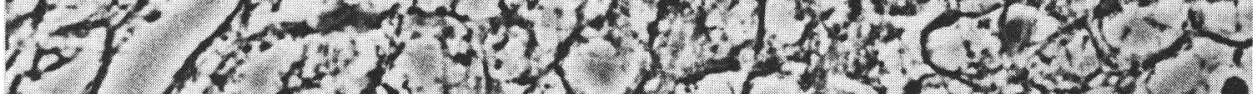

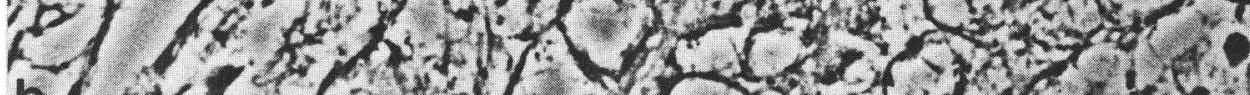

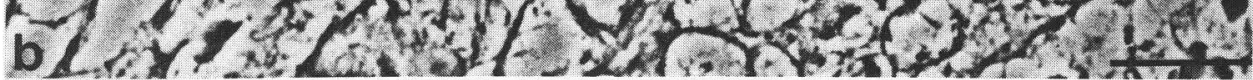



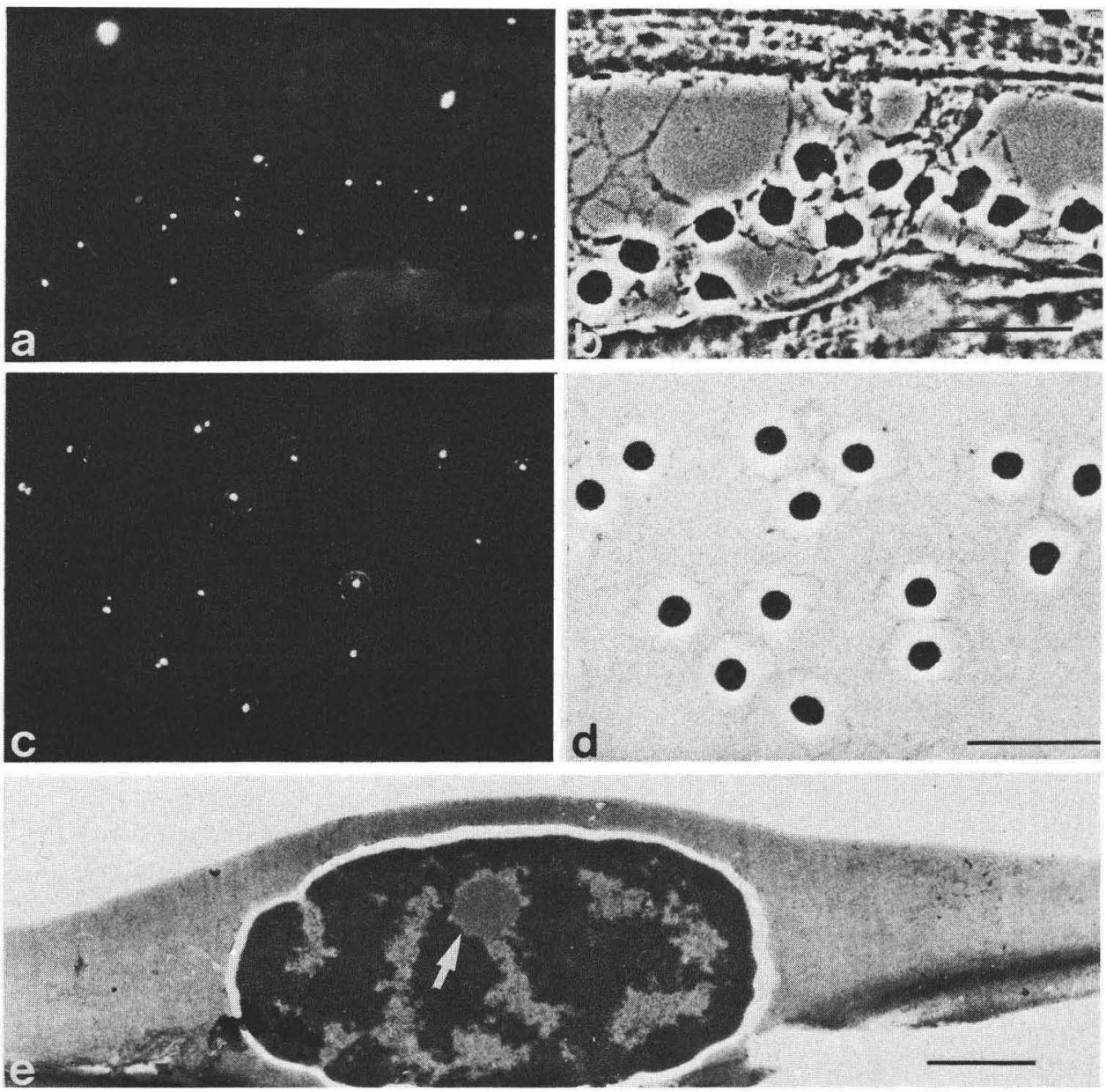

Fig. 7. Nuclei of Xenopus laevis erythrocytes, which have been reported to lack RNA polymerase I transcriptional activity, contain one to two small fluorescing entities, as seen after incubation of cryostat sections through blood vessels of $(a)$ heart muscle or $(c)$ blood smears with antibody No-114. $(b, d)$ Corresponding phase contrast images; $(e)$ residual nucleolar structure (arrow) seen in an electron micrograph of a section through a Xenopus laevis erythrocyte. Bar, (a,c) $20 \mu \mathrm{m} ;(e) 1 \mu \mathrm{m}$.

relatively large nucleoli of Sertoli cells as well as in nucleolar structures of spermatogonia and spermatocytes and in interstitial cells, whereas spermatids and spermatozoa were negative, in agreement with the absence of nucleoli in these cells.

Fig. 6. Immunofluorescence microscopy on frozen sections through Xenopus laevis liver as seen with $(a)$ epifluorescence; $(b)$ phase contrast optics after incubation with cell culture supernatant from hybridoma clone No-114. In the hepatocytes, the relatively large nucleoli show intense fluorescence, whereas nucleoplasm and cytoplasm are negative. Nucleoli of most mesenchymal cells and nucleolar residue bodies of erythrocytes appear as small fluorescent dots. Bar, $20 \mu \mathrm{m}$. 
In some tissues of Xenopus, careful examination revealed the presence of at least two distinct nucleoli, both of which were positively stained by antibody No114, in agreement with the presence of two transcriptionally active nucleolar organizers in this species [36]. Fig. $5 \mathrm{c}$ presents an example, showing myocardial tissue.

Interestingly, erythrocytes identified in liver (fig. 6), in myocardiac blood vessels (fig. $7 a, b$ ) and in other tissues revealed one or two small 'dots' strongly stained by antibody No-114. This positive reaction was also observed in erythrocytes of blood smears of Xenopus laevis (fig. $7 c, d$ ). Such dots seem to correspond to the 'residual nucleolar structure' seen in electron micrographs of erythrocytes of amphibia (fig. 7e; cf [37]) and birds [37-40] which have been reported to be inactive in rDNA transcription and to lack RNA polymerase I [40-43].

\section{Immunofluorescence Microscopy on Cultured Cells}

The nucleolar specificity of antibody No-114 was also demonstrated in cultured cells which were grown on coverslips and processed for immunofluorescence microscopy as whole mount preparations (fig. $8 a, a^{\prime}$ ). The usually higher resolution of this technique allowed to distinguish, in most nucleoli, a variable number of distinct subnucleolar structures which bound the antibody in contrast to other nucleolar regions which were not stained (fig. $8 a, a^{\prime}$ ). When such preparations were exposed to relatively high concentrations of No-114 antibody it was found that staining was not completely restricted to the nucleoli proper but that some small nucleoplasmic 'dots' were also fluorescent (fig. $8 b, b^{\prime}$ ). The staining patterns of antibodies to polymerase I and to ribosomal protein S1 were clearly different (cf [11, 44]). Likewise, the spheroidal subunits at the nucleolar periphery and in the nucleoplasm which are detected by antibodies to the karyoskeletal protein of $M_{r} 145000$ appeared to be different when examined in double label experiments (not shown; see [13]).

A remarkable transition of the antigen was noted during mitosis. In prophase the major nucleolar units were still positive, but in addition some smaller components of various sizes, probably nucleolus-derived fragments, were also stained (fig. $8 c, c^{\prime}$ ). In metaphase and early anaphase, only weak and diffuse cytoplasmic fluorescence was seen. The chromosomal nucleolar organizer regions were not

Fig. 8. Localization of No-114 antigen by indirect immunofluorescence microscopy in $(a, b)$ interphase cells and $(c-f)$ during mitosis of cultured kidney epithelial cells of Xenopus laevis line $\mathrm{A}_{6}$; $\left(a^{\prime}, b^{\prime}, c^{\prime}-f^{\prime}\right)$ corresponding phase contrast images. Nucleoli of interphase cells are brightly fluorescing $(a, b)$ and usually reveal several fluorescing subnucleolar components (e.g., nucleoli denoted in $a^{\prime}$ (arrows)). (b) In addition, small fluorescing dot-like structures surrounding the nucleoli are sometimes also seen. In early mitotic prophase $\left(c, c^{\prime}\right)$ the nucleolus disintegrates and the No-114 antigen is located in several nuclear granules, some of which may represent the fragmenting nucleoli. During $\left(d, d^{\prime}\right)$ metaphase and $\left(e, e^{\prime}\right)$ anaphase only very weak and diffuse cytoplasmic fluorescence is observed. When the nucleolar structure begins to re-assemble in late telophase $\left(f, f^{\prime}\right)$ the antibody again stains granular structures inside the newly formed nuclei, indicating that the antigen is recollected in the nucleolus, re-assuming its interphase functions. Bar, $20 \mu \mathrm{m}$. 

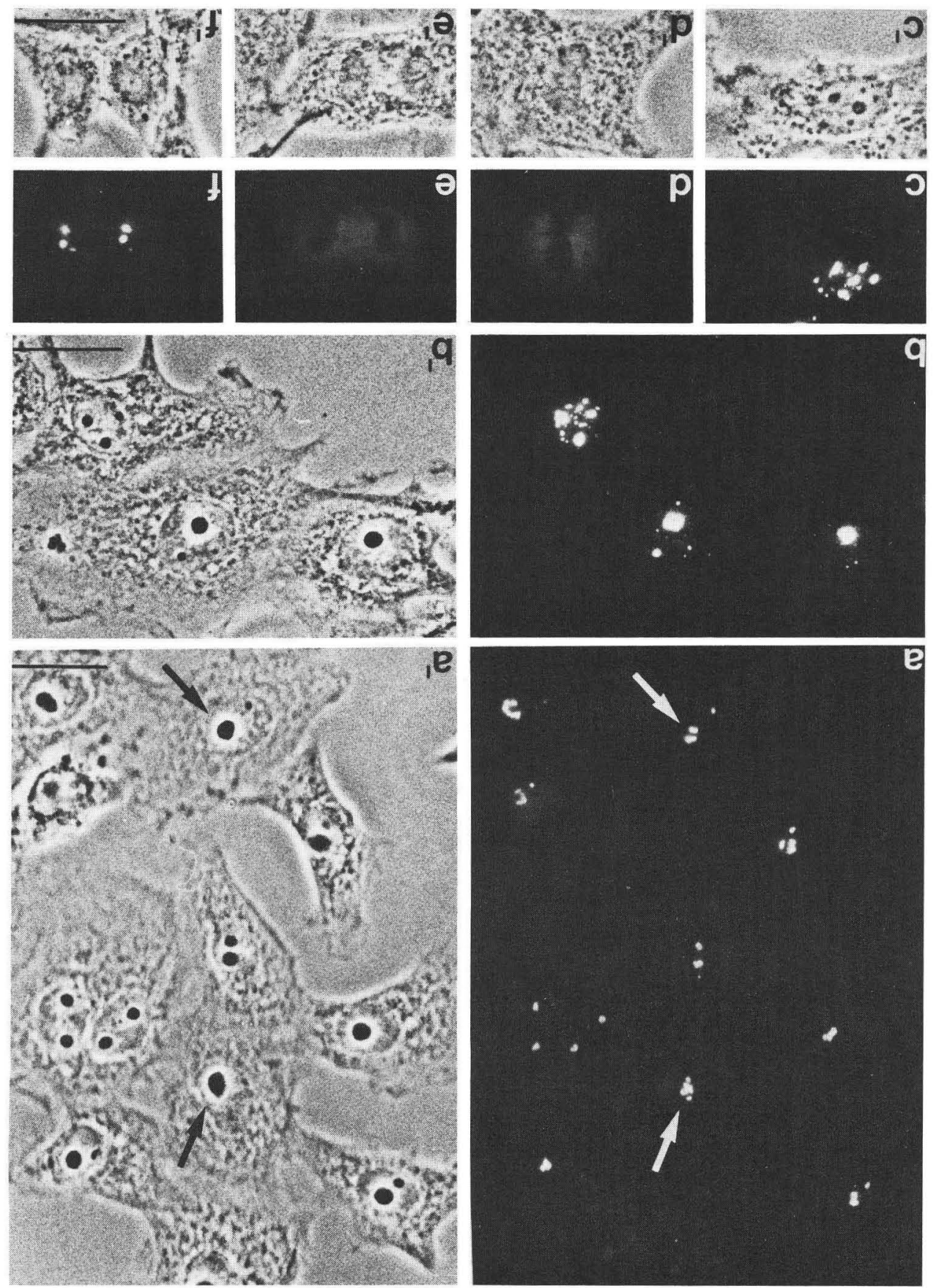

3
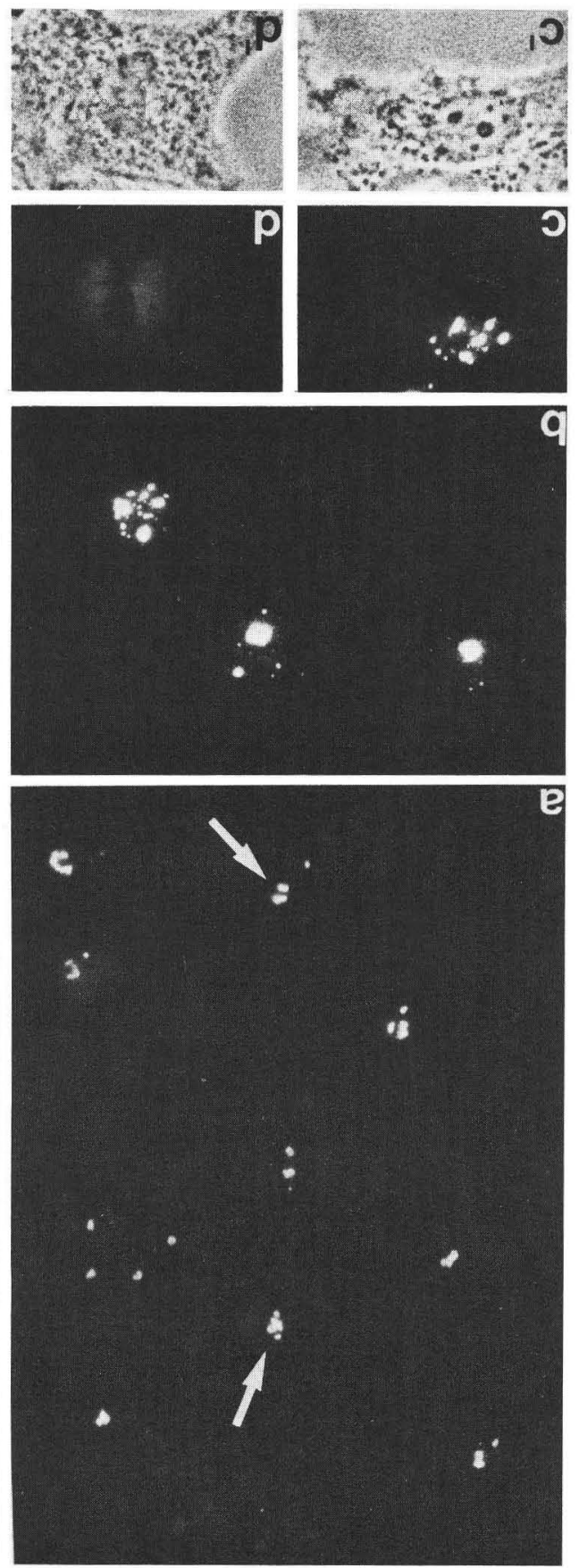

e

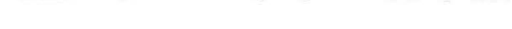




\section{Schmidt-Zachmann et al.}

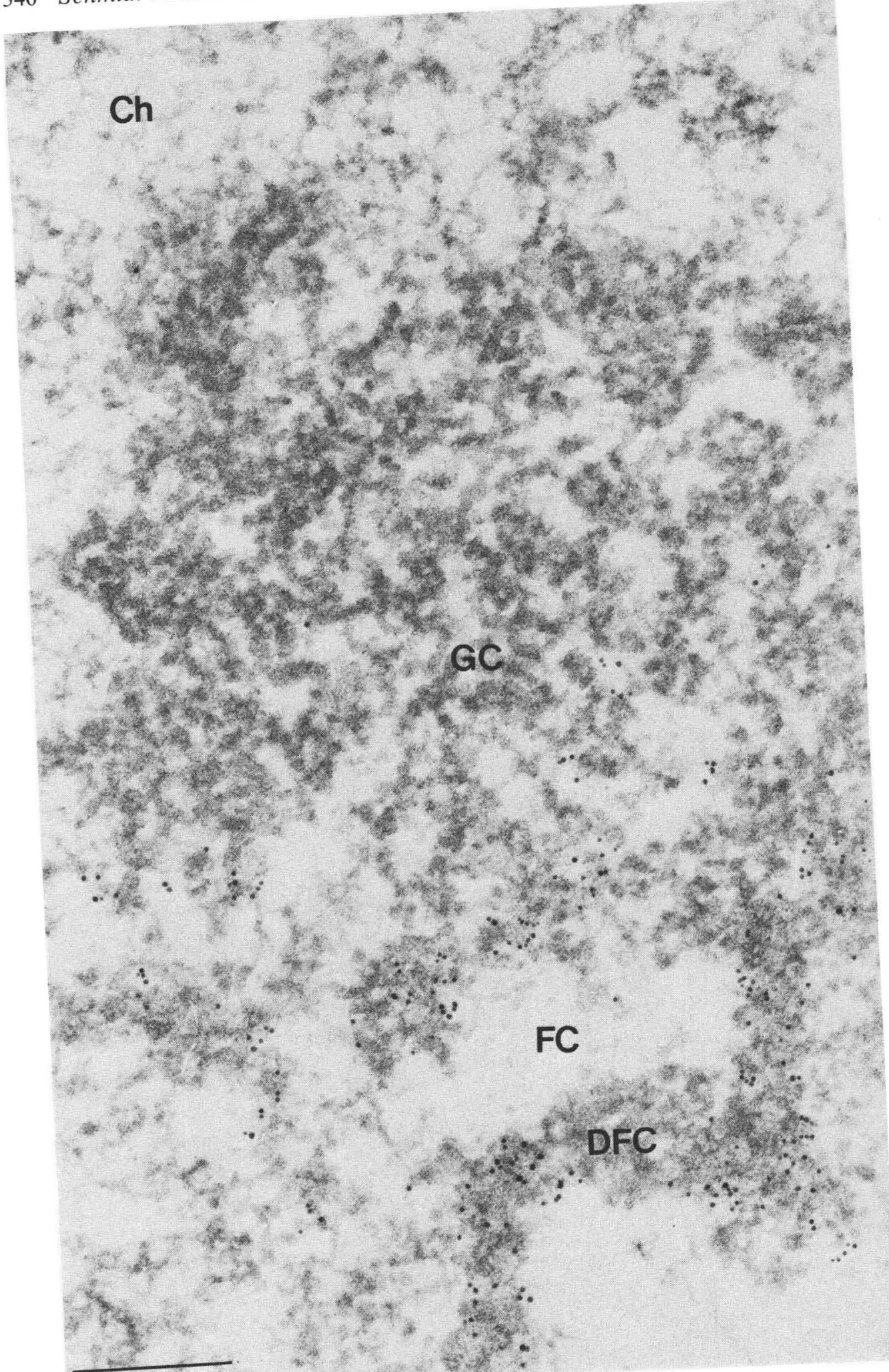


stained by No-114 (fig. $8 d, d^{\prime}$ and $e, e^{\prime}$ ), in contrast to their staining with antibodies to other typical nucleolar markers such as RNA polymerase I [11]. In telophase, No-114 fluorescence was again found to be concentrated in the reforming nucleoli (fig. $8 f, f^{\prime}$ ).

\section{Electron Microscopic Immunolocalization}

After using secondary antibodies coupled to colloidal gold particles, we examined the distribution of antibody binding on frozen sections of ovaries, myocardium, and liver and found a specific decoration of the curved broad bands of the 'dense fibrillar component' of the nucleolus (for nomenclature see [3, 45]). Other distinct nucleolar substructures such as the 'fibrillar centres', which are known to contain RNA polymerase I [11], the 'granular component' known to contain preribosomal particles in late stages of maturation [1-9], and the peripheral karyoskeletal filamentous aggregates [12-15] all were not significantly labelled by the No-114 antibodies.

\section{Localization of the $M_{r} 180000$ Protein in Segregated Nucleoli}

Inactivated nucleoli, whether naturally occurring or experimentally induced, show a typical segregation of the fibrillar component from the granular component, usually resulting in the formation of distinct nucleolar hemispheres (for references see $[1,46,47])$. We induced this nucleolar segregation by treatment of A6 cells with actinomycin D. The resulting nucleolar hemisphere or 'cap', i.e., the fibrillar component which appeared light in phase optics, was stained intensely by antibody No-114 (fig. 10 $a, b$ ) but was negative for the monoclonal antibody to ribosomal protein S1. In contrast, the other hemisphere, which appeared dark in phase optics and contained the granular component, was negative for antibody No-114 but strongly positive for antibody RS1-105 directed against ribosomal protein S1. Antibodies to RNA polymerase I stained a small crescent at the outermost margin of the segregated fibrillar component, which we interpret to be the inactivated form of the fibrillar centre (data not shown). Antibodies to the $M_{r}$ 145000 protein of nucleolar 'skeletal' filaments stained a few distinct bodies in the periphery of the nucleolus.

\section{Interspecies Cross-reactivity of Antibody No-114}

Practically identical results were obtained, with oocytes and somatic cells, of $X$. laevis and $X$. borealis. However, antibody No-114 did not show significant reaction in immunofluorescence microscopy using sections and cultured cells

Fig. 9. Electron microscopic immunolocalization of No-114 antigen in Xenopus laevis hepatocyte nucleolus by immuno-gold labelling. The dense fibrillar component $(D F C)$ is specifically labelled, whereas fibrillar centres $(F C)$ and the granular component $(G C)$ as well as the surrounding chromatin $(\mathrm{Ch})$ are free of gold particles. Bar, $0.2 \mu \mathrm{m}$. 

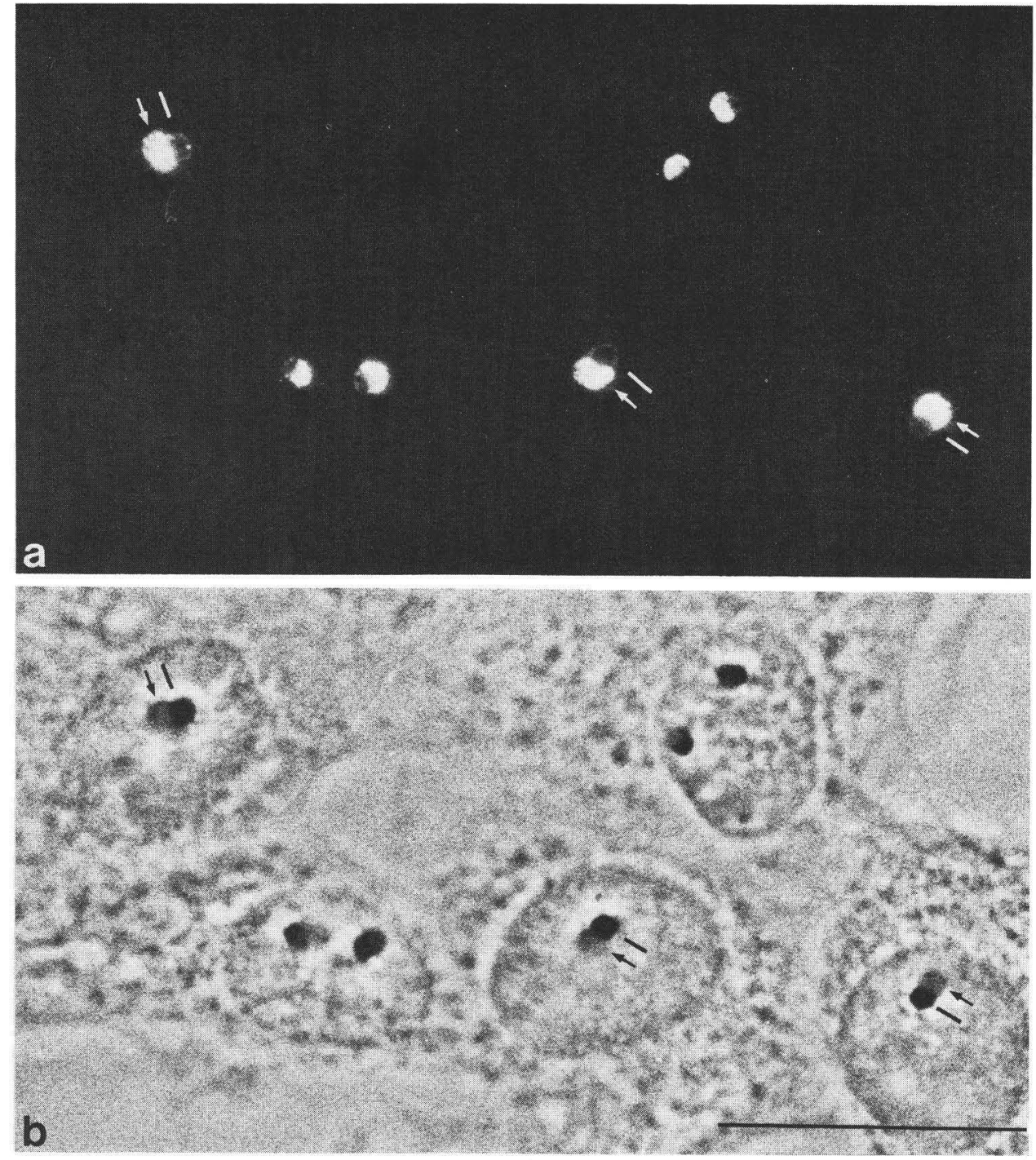

Fig. 10. Localization of No-114 antigen in (a) actinomycin D-treated cultured cells of Xenopus laevis ( $\mathrm{A}_{6}$ line) by immunofluorescence microscopy. (b) In the phase-contrast image, segregation of druginactivated nucleoli into two components, a phase-light (arrows) and a phase-dark (bars) hemisphere, is clearly seen. Note the specific decoration on the phase-light, i.e., the fibrillar component, by the No-114 antibody. Bar, $20 \mu \mathrm{m}$.

from other amphibia (Rana, Triturus, Pleurodeles) as well as from chicken, rat, and man, indicating that the specific determinant is absent in genera other than Xenopus. Likewise, we did not observe a significant reactivity of antibody No114 in immunoblotting experiments, using total nuclear proteins from oocytes of Rana and Pleurodeles and from rat liver. 


\section{DISCUSSION}

The $M_{r} 180000$ protein described in this study is a novel nucleolar protein specific for the dense fibrillar component. It is present not only as a major component in transcriptionally active nucleoli but also occurs in the residual nucleolar structure of transcriptionally inactive amphibian erythrocytes and in the fibrillar component of segregated nucleoli formed after drug-induced inhibition of transcription. As judged from our gel electrophoretic analyses of the fractions enriched in extrachromosomal nucleoli of Xenopus oocytes, it is among the abundant nucleolar polypeptides. A polypeptide band of similar size can also be detected in the fractions presented by Higashinakagawa et al. [48]. The finding that our antibody No-114 does not recognize a corresponding protein in avian and mammalian cells probably reflects a species-difference in the antigenic determinant rather than the absence of a related protein in higher vertebrates.

The $M_{r} 180000$ protein does not seem to be identical with any of the nucleolar proteins so far identified in various species. Clearly, its high molecular weight, its low isoelectric point, and its absence from the granular component distinguish it from ribosomal proteins (for a review see [49]). Likewise, the $M_{r} 180000$ protein seems to be unrelated to mammalian nucleolar protein $\mathrm{C} 23\left(M_{r} 110000\right.$; isoelectric $\mathrm{pH}$ 5.9) described by Busch and colleagues [18], which has also been reported to remain associated with the nucleolar organizer region during mitosis [50]. It also seems to be different from the nucleolar protein of $M_{r} 100000$ of cultured Chinese hamster ovary cells which has been found in association with nascent pre-rRNA and preribosomes [20]. Whether the $M_{r} 180000$ protein of Xenopus is related to the much smaller mammalian heat shock protein of $M_{r} 110000$ which has been localized in the fibrillar component of segregated nucleoli of postconfluent Chinese hamster ovary cells [51] cannot be decided at the moment. The karyoskeletal nucleolar protein of $M_{r} 145000$ and an isoelectric $\mathrm{pH}$ of approx. 6.2 $[12,13]$ is clearly different from the protein described in the present study. RNA polymerase I, of course, is a nucleolar protein component that contains a polypeptide subunit of a similar size [52]. However, the $M_{r} 180000$ protein identified by antibody No-114 does not seem to be identical with the large subunit of RNA polymerase I for the following reasons. (1) It is localized exclusively in the dense fibrillar component, in contrast to the transcriptionally active polymerase I which has been shown to be located in the fibrillar centre [11]. (2) During mitosis, polymerase I molecules remain in association with the nucleolus organizer region (NOR) of metaphase chromosomes [11], whereas the $M_{r} 180000$ protein is not detected on chromosomes. (3) Amphibian erythrocytes, which have been reported to lack RNA polymerase I ([43]; for avian erythocytes see also [42]), contain a significant amount of the $M_{r} 180000$ protein associated with the residual nucleolar structure. (4) In segregated nucleoli of actinomycin D-treated cells, antibodies to polymerase I localize differently from antibodies to the $M_{r} 180000$ protein (see Results). (5) After release by elevated ionic strength, the $M_{r} 180000$ polypeptide appears as 7-8S protein, whereas the holoenzyme forms of RNA polymerase I 
and other RNA polymerases have been reported to sediment at 13-15S [53, 54]. (6) In addition, the preparations enriched in solubilized $M_{r} 180000$ protein do not show, on gel electrophoresis, equivalent amounts of the smaller polypeptide subunits characteristic of RNA polymerases.

We conclude that the $M_{r} 180000$ protein is a nucleolar constituent sui generis. Moreover, it is specifically located in the dense fibrillar component of the nucleolus and thus provides a specific marker for this structure. On the whole, this protein seems to be related to the structural organization of the interphase nucleolus and does not represent a constituent of the transcriptional complex or of nucleolar ribonucleoprotein products, as it is maintained in transcriptionally inactive nucleolar residue structures. On the other hand, within the fibrillar component it may be associated with ribonucleoprotein material, at least in the transcriptionally active nucleoli of Xenopus oocytes, since a considerable proportion of it is released upon treatment of nucleoli with RNase. Yet, the absence of the $M_{r} 180000$ protein from the granular portion of the nucleolus, which is known to contain preribosomal particles [1-9] and is positively decorated by antibodies to ribosomal proteins such as S1 (these authors, unpublished observation), indicates that this large protein is not associated with ribonucleoproteins of preribosomal particles at this stage of processing. We suggest that the $M_{r} 180000$ protein contributes to the dense backbone structure of the fibrillar component of the nucleolus, providing support to elements involved in transcription and/or processing of rDNA products.

The distribution of the nucleolar protein of $M_{r} 180000$ during mitosis is remarkable. In prophase, it appears to be released during nucleolar disintegration, then becomes dispersed away from the chromosomes during metaphase and early anaphase, but is rapidly re-accumulated on the reforming nucleolus in telophase. Thus it appears that the $M_{r} 180000$ protein re-enters rapidly the reforming nucleus, suggesting the existence of a specific nuclear accumulation mechanism for this protein. In contrast, other nucleolar proteins, such as RNA polymerase I [11], protein C23 [50,55] and the argyrophilic nucleolar protein(s) in general $[36,39,55]$, have been shown to remain associated with the NOR of metaphase chromosomes. A third pattern of behaviour has been reported for ribonucleoprotein material containing ribosomal precursors which remain in association with metaphase chromosomes [56] but in a more spread out fashion, seemingly enriched on the surfaces of metaphase chromosomes, as demonstrated specifically for preribosomal protein B23 [55]. Pronounced staining on metaphase chromosome surfaces has also been noted, in addition to the general disperse cytoplasmic staining which includes mature ribosomes, in our immunofluorescence microscopic studies using the monoclonal antibody RS1-105 against ribosomal protein S1 (these authors, unpublished observations). Therefore, the distribution of the nucleolar protein of $M_{r} 180000$ during mitosis, notably in telophase, points to the existence of mechanisms which results not only in a nuclear accumulation of this protein but also in its specific assembly in a distinct sub- 
structure of the nucleolus, the dense fibrillar component. Future experiments will have to show whether this is due to self-assembly of the $M_{r} 180000$ protein and what nucleolar material is responsible for the topologically specific nucleation of this accumulation.

We thank Dr G. Moldenhauer (Institute of Immunology and Genetics, this center) and Dipl. Phys. M. Stöhr (Institute of Experimental Pathology, this center) for valuable experimental help. We are indebted to Drs K. Rose (Department of Pharmacology, Medical School, The University of Texas, Houston, Texas) and G. Krohne (this institute) for their generous gifts of antibodies used for comparative purposes. The work has been supported in part by the Deutsche Forschungsgemeinschaft (DFG, grant No. Sche 157/5-3).

\section{REFERENCES}

1. Busch, H \& Smetana, K, The nucleolus. Academic Press, New York (1970).

2. Hadjiolov, A A \& Nikolaev, N, Próg biophys molec biol 31 (1976) 95.

3. Bouteille, M, Hernandez-Verdun, D, Dupuy-Coin, A M \& Bourgeois, C A, The nucleolus (ed E G Jordan \& C A Cullis) p. 179. Cambridge University Press, Cambridge (1982).

4. Granboulan, N \& Granboulan, Ph, Exp cell res 38 (1965) 604.

5. Fakan, S \& Bernhard, W, Exp cell res 67 (1971) 129.

6. Fakan, S, The cell nucleus (ed H Busch) vol. 5, p. 3. Academic Press, New York (1978).

7. Fakan, S \& Puvion, E, Int rev cytol 65 (1980) 255.

8. Puvion, E \& Moyne, G, The cell nucleus (ed H Busch) vol. 8, p. 59. Academic Press, New York (1981).

9. Smetana, K \& Busch, H, The cell nucleus (ed H Busch) vol. 1, p. 75. Academic Press, New York (1974).

10. Rose, K M, Stetler, D A \& Jacob, S T, Proc natl acad sci US 78 (1981) 2833.

11. Scheer, U \& Rose, K M, Proc natl acad sci US 81 (1984) 1431.

12. Franke, W W, Kleinschmidt, J A, Spring, H, Krohne, G, Grund, C, Trendelenburg, M F, Stoehr, M \& Scheer, U, J cell biol 90 (1981) 289.

13. Krohne, G, Stick, R, Kleinschmidt, J A, Moll, R, Franke, W W \& Hausen, P, J cell biol 94 (1982) 749 .

14. Benavente, R, Krohne, G, Stick, R \& Franke, W W, Exp cell res 151 (1984) 224.

15. Moreno Diaz de la Espina, S, Franke, W W, Krohne, G, Trendelenburg, M F, Grund, C \& Scheer, U, Eur j cell biol 27 (1982) 141.

16. Hay, E D \& Gurdon, J B, J cell sci 2 (1967) 151.

17. Busch, H, Chromosomal nonhistone proteins (ed L S Hnilica) vol. 4, p. 233. CRC Press, Boca Raton, Fla (1984).

18. Busch, H, Busch, R K \& Chan, P K, Chromosomal nonhistone proteins (ed L S Hnilica) vol. 2, p. 57. CRC Press, Boca Raton, Fla (1983).

19. Daskal, Y, Smetana, K \& Busch, H, Exp cell res 127 (1980) 285.

20. Bugler, B, Caizergues-Ferrer, M, Bouche, G, Bourbon, H \& Amalric, F, Eur j biochem 128 (1982) 475.

21. Franke, W W, Schmid, E, Winter, S, Osborn, M \& Weber, K, Exp cell res 123 (1979) 25.

22. Scalenghe, F, Buscaglia, M, Steinheil, C \& Crippa, M, Chromosoma 66 (1978) 299.

23. Kleinschmidt, J A \& Franke, W W, Cell 29 (1982) 799.

24. Köhler, G \& Milstein, C, Nature 256 (1975) 495.

25. Ouchterlony, Ö \& Nilsson, L- ̊, Handbook of experimental immunology (ed D M Weir) vol. 1, p. 19.1. Blackwell Scientific Publications, London (1978).

26. Krohne, G, Franke, W W, Ely, S, D’Arcy, A \& Jost, E, Cytobiol 18 (1978) 22.

27. Hügle, B, Kleinschmidt, J A \& Franke, W W, Eur j cell biol 32 (1983) 157.

28. Laemmli, U K, Nature 227 (1970) 680.

29. Thomas, J O \& Kornberg, R D, Proc natl acad sci US 72 (1975) 2626.

30. O'Farrell, P Z, Goodman, H M \& O'Farrell, P H, Cell 12 (1977) 1133.

31. Moll, R, Franke, W W, Schiller, D L, Geiger, B \& Krepler, R, Cell 31 (1982) 11. 
32. Switzer, R C, Merril, C R \& Shifrin, S, Anal biochem 98 (1979) 231.

33. Bowen, B, Steinberg, J, Laemmli, U K \& Weintraub, H, Nucl acid res 8 (1980) 1.

34. Towbin, H, Staehelin, T \& Gordon, J, Proc natl acad sci US 76 (1979) 4350.

35. Hunter, W M, Handbook of experimental immunology (ed D M Weir) vol. 1, p. 14.1. Blackwell Scientific Publications, London (1978).

36. Howell, W M, The cell nucleus (ed H Busch \& L Rothblum) vol. 11, p. 90. Academic Press, New York (1982).

37. Smetana, K \& Likovski, Z, Exp cell res 69 (1971) 65.

38. - Cytobiol 17 (1978) 146.

39. Hernandez-Verdun, D, Hubert, J, Bourgeois, C A \& Bouteille, M, Chromosoma 79 (1980) 349.

40. Laval, M, Hernandez-Verdun, D \& Bouteille, M, Exp cell res 132 (1981) 157.

41. Zentgraf, H, Scheer, U \& Franke, W W, Exp cell res 96 (1975) 81.

42. Krüger, C \& Seifart, K H, Exp cell res 106 (1977) 446.

43. Hentschel, C C \& Tata, J R, Dev biol 65 (1978) 496.

44. Scheer, U, Hügle, B, Hazan, R \& Rose, K M. Submitted for publication.

45. Hernandez-Verdun, D, Biol cell 49 (1983) 191.

46. Bernhard, W, Advances in cytopharmacology (ed F Clementini \& B Ceccarelli) vol. 1, p. 49. Raven Press, New York (1971).

47. Simard, R, Langelier, Y, Mandeville, R, Maestracci, N \& Royal, A, The cell nucleus (ed H Busch) vol. 3, p. 447. Academic Press, New York (1974).

48. Higashinakagawa, T, Wahn, H \& Reeder, R H, Dev biol 55 (1977) 375.

49. Bielka, H, The eucaryotic ribosome. Springer-Verlag, Berlin, Heidelberg, New York (1982).

50. Lischwe, M A, Richards, R L, Busch, R K \& Busch, H, Exp cell res 136 (1981) 101.

51. Subjeck, J R, Shyy, T, Shen, J \& Johnson, R J, J cell biol 97 (1983) 1389.

52. Engelke, D R, Shastry, B S \& Roeder, R G, J biol chem 258 (1983) 1921.

53. Matsui, T, Onishi, T \& Muramatsu, M, Eur j biochem 71 (1976) 351.

54. Chambon, P, Annual review of biochemistry (ed E E Snell, P D Boyer, A Meister \& C C Richardson) vol. 44, p. 613. Palo Alto, Calif. (1975).

55. Ochs, R, Lischwe, M, O'Leary, P \& Busch, H, Exp cell res 146 (1983) 139.

56. Fan, H \& Penman, S, J mol biol 59 (1971) 27.

57. Hügle, B, Hazan, R, Scheer, D \& Franke, W W. In preparation.

Received March 12, 1984 